\title{
Notching Techniques Increase Branching of Young Apple Trees
}

\author{
Duane W. Greene and Wesley R. Autio \\ Department of Plant and Soil Sciences, University of Massachusetts, Amherst, MA 01003
}

Additional index words. apical dominance, lateral branching, Malus domestica, shoot growth, tree training

\begin{abstract}
Apple trees (Malus domestica Borkh.) were notched with a hacksaw blade by removing a 2-mm-wide strip of bark from directly above a bud. The cut extended down to the secondary xylem and around about one-third of the circumference of the stem. The most effective time to notch was $\approx 2$ to 4 weeks before full bloom. Notching was most effective at inducing shoot growth from buds on the top of a branch, less effective for buds on the side, and least effective for buds on the underside of a branch. On untreated controls, the most shoots grew from the upper one-third of 1- or 2-year-old growth, and very few shoots developed buds on the lower one-third. If a bud was notched, however, the pattern was similar and incidence of shoot development was high. The percentage of notched buds that developed into shoots was not influenced by wood age. There was a positive, linear relationship between bud size and the percentage of buds growing into lateral shoots and between bud size and the length of those lateral shoots. Over all years, experiments, and cultivars, notching increased shoot production $\approx 600 \%$.
\end{abstract}

Rapid development of scaffold branches and secondary branches in a young apple tree is a prerequisite for early production (Looney, 1980; Quinlan and Preston, 1978). Spraying benzyladenine (BA) or Promalin $\left[\mathrm{BA}+\right.$ gibberellin $\left.\mathrm{A}_{4+7}\left(\mathrm{GA}_{4+7}\right)\right]$ is the most frequently cited method to increase branching, and its effectiveness has been established in several studies (Elfving, 1985; Forshey, 1982; Greene and Miller, 1988). Chemicals have not been used widely by the industry, however, because it is difficult to regulate the number of lateral shoots produced, and frequently the lateral shoots that are produced are too short to develop into satisfactory scaffold branches. Additionally, the rates of Promalin required to stimulate branching can thin developing fruit and inhibit flower bud formation (Greene et al., 1990).

Cultural techniques also can increase branching on young trees. Pruning into 1-year-old wood increases lateral branching (Ferree, 1981). This type of pruning, however, reduces potential fruiting surface and creates a cluster of branches near the cut that have narrow, undesirable crotch angles (Elfving and Forshey, 1976; Lord and Damon, 1983). Limb spreading can stimulate lateral branching, but fewer branches are produced (Forshey, 1982). Leaf removal also increases branching, but, to be effective, the youngest cupped leaves surrounding the apical meristem must be removed (Wertheim, 1978). Popenoe and Barritt (1988) confirmed this requirement on spur-type 'Delicious' but concluded that the treatment was not satisfactory because the lateral shoots that are produced by this method often are too short to be useful.

Notching is a technique that has been noted in several pomology textbooks as a method to stimulate lateral branching (Auchter and Knapp, 1929; Chandler, 1925; Gardner et al., 1939). Swales (1976) recommended its use to stimulate branching on lop-sided trees. Verner (1955) reported that notching was useful to increase the growth of lateral shoots, but, to be effective, it had to be done at bud break or soon thereafter. Oberhofer (1990) recommended that notching be done shortly before the beginning of the growing season. Notching has never become a wide-spread commercial practice, however, perhaps due largely to the observation made by

Received for publication 11 May 1992. Accepted for publication 20 May 1993. Paper no. 3062 of the Massachusetts Agricultural Experiment Station, Univ. of Massachusetts, Amherst. This research was supported in part by Experiment Station project no. 696. The cost of publishing this paper was defrayed in part by the payment of page charges. Under postal regulations, this paper therefore must be hereby marked advertisement solely to indicate this fact.
Gardner et al. (1939) that the results were somewhat erratic and, therefore, unpredictable.

Factors influencing the effectiveness of notching have not been studied thoroughly. We speculated that inconsistent results with notching may have been due to a lack of understanding of the variables that affect bud growth after notching. Therefore, we designed a series of experiments to identify factors that influence the response of young apple trees to notching.

\section{Materials and Methods}

Plant material. All experiments in this investigation were conducted at the Univ. of Massachusetts Horticultural Research Center, Belchertown.

Notching. Notching was done with an ordinary hacksaw blade. Buds were notched by placing the blade immediately above a bud and drawing the blade across the branch. A strip of bark $2 \mathrm{~mm}$ wide down to the secondary xylem was removed. This cut extended on each side of the bud and around about one-third of the circumference of the stem (Fig. 1).

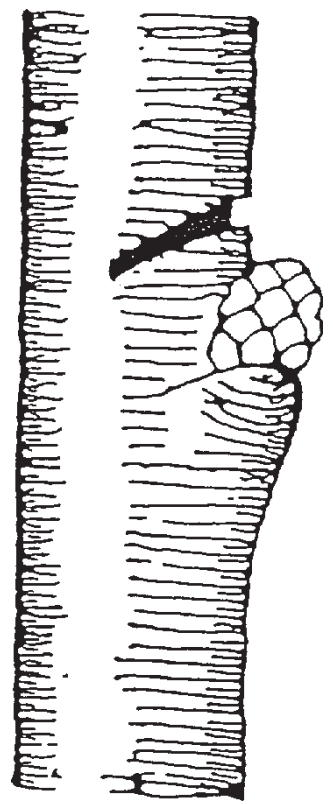

Fig. 1. Notching above apple vegetative bud (Oberhofer, 1990). 
Application time (Expt. 1). A block of 9-year-old 'Redspur Delicious'/MM.111 was selected and divided into 11 uniform replications of six trees each. In the middle of March, 12 spur buds of similar size were selected on 2-year-old wood and marked with white paint. All marked buds on one tree per replication were notched on 31 Mar., 11 Apr., 23 Apr., 8 May, or 22 May, ₹6, 4, or 2 weeks before anticipated full bloom, at full bloom, or 2 weeks after full bloom, respectively. Trees reached silver tip on 4 Apr., green tip on $10 \mathrm{Apr}$., and $1.2 \mathrm{~cm}$ (half-inch) green on $23 \mathrm{Apr}$. Buds on one tree per replication were not notched and served as a control. After leaves abscissed in November, all marked buds or shoots were measured and the number of buds with shoots $\geq 5 \mathrm{~cm}$ was recorded.

Bud location (Expt. 2.). Twenty 4-year-old 'Spigold'/M.7 trees were selected and paired into 10 replications. Two buds were randomly selected on the top, side, and bottom of the 1-year-old portion of five limbs per tree. One bud at each location on each limb was notched 22 Apr., 2.5 weeks before full bloom. The remaining bud at each location was not notched and served as the control. The length of shoots from marked buds was measured after leaf abscission in November.

Promalin, limb type, and bud location (Expt. 3). Twenty-eight 3-year-old 'Spurcort'/M.7 were grouped in seven replications of four trees each. White paint was used to mark one bud at the tip, in the middle, and at the base of 1-year-old wood on the central leader and on four scaffold branches of all trees in the experiment. About 3 weeks before full bloom, all marked buds on two trees per replication were notched. Promalin at $300 \mathrm{mg} \cdot$ liter $^{-1}$ was applied on 21 May to the drip point on one notched and one unnotched tree per replication, when terminal growth was $\approx 6 \mathrm{~cm}$ long. One tree in each replication was not treated and served as a control. Growth data were taken in November, similar to those described in Expt. 1.

Wood age and bud location (Expt 4.). Sixty 3-year-old 'Marshall McIntosh'/M.26 were grouped into 10 replications of six trees each. One bud at the tip, middle, and base of 1-year-old and 2-year-old portions of the central leader were marked with paint in March. All buds on three of the six trees in each replication were notched on 22 Apr., $\approx 3$ weeks before full bloom. The remaining three trees per replication were not notched and served as controls. Growth measurements similar to those described previously were taken in November.

Bud size (Expt. 5). Eighty 4-year-old 'Marshall McIntosh'/ M.26 were selected and grouped into eight replications of 10 trees each. One bud $<4 \mathrm{~mm}$ in diameter, one between 4 and $5 \mathrm{~mm}$, and one $>5 \mathrm{~mm}$ were selected and measured in March on the 2-year-old portion of the central leader. The bud size categories were identified with paint. Buds on five trees per replication were notched on $20 \mathrm{Apr}$. Buds on the remaining five trees in each replication were not notched and served as controls. The buds that flowered were identified at the pink stage, and fruit set on these buds was determined at the end of June drop in July. Growth of identified buds was determined as previously described.

Statistical analysis. Analysis of variance was used in all experiments to determine significance and, where appropriate, orthogonal polynomial comparisons or Duncan's new multiple range tests were used to separate means.

\section{Results}

Time of notching (Expt. 1). Notching significantly increased the number and length of spurs that grew into lateral shoots (Table 1). The response was quadratic. Notching stimulated more shoot production and the growth of longer shoots when it was done 2 or 4 weeks before full bloom than at other times. Notching done earlier or later stimulated shoot production, but it was not nearly as effective.

Bud location (Expt. 2). Unless notched, few if any buds on 'Spigold' branches grew into lateral shoots (Table 2). Notching significantly increased lateral branching, but there was a notching $\times$ location interaction for shoot production and the resulting shoot length. Notching stimulated more buds on the top portion of a branch to grow, an intermediate number of buds on the side, and the fewest buds at the bottom. Unless notched, no buds located on the side or bottom of a shoot grew into a lateral shoot. Shoots stimulated to grow from a bud on the top of a branch were longer than those originating from other locations.

Promalin, limb type, and bud location (Expt. 3). Notching and Promalin increased lateral branching on 'Spurcort Cortland'. There was a notching $\times$ location interaction (Fig. 2) and a notching $\times$ location $\times$ branch type interaction on shoot initiation (Table 3 ). When buds were not notched, a higher percentage of the buds at the tip of a shoot grew into lateral shoots than from buds located in the middle or in the base of shoots. This relationship was highly significant, negative, and linear. When buds were notched, the number of buds that grew into lateral shoots was similar, regardless of the location of the bud on the shoot. There was a notching $x$

Table 1. Effect of time, relative to full bloom (FB), of notching 2-year-old spurs on the incidence of shoot production and shoot length of 9-year-old 'Redspur Delicious'-MM.111 (Expt. 1).

\begin{tabular}{lcr}
\hline \hline $\begin{array}{l}\text { Time notched } \\
\text { relative to FB } \\
\text { (days) }\end{array}$ & $\begin{array}{c}\text { Shoots } \\
\geq 5 \mathrm{~cm}\end{array}$ & $\begin{array}{c}\text { Shoot } \\
\text { length } \\
(\%)\end{array}$ \\
\hline No notch & 3 & 2.7 \\
-6 & 42 & 8.4 \\
-4 & 61 & 11.0 \\
-2 & 59 & 11.3 \\
0 & 46 & 8.0 \\
2 & 14 & 5.1 \\
Significance & & $* *$ \\
Linear & $* *$ & $* *$ \\
Quadratic & $* *$ &
\end{tabular}

S* Significant at $P \leq 0.01$.

Table 2. Effect of notching above buds on 1-year-old wood and of bud location on the incidence of shoot production and shoot length of 4-year-old 'Spigold'-M.7 (Expt. 2). ${ }^{\mathrm{Z}}$

\begin{tabular}{|c|c|c|c|}
\hline \multicolumn{2}{|c|}{ Treatment } & \multirow{2}{*}{$\begin{array}{c}\text { Shoots } \\
\geq 5 \mathrm{~cm} \\
(\%)\end{array}$} & \multirow{2}{*}{$\begin{array}{l}\text { Shoot } \\
\text { length } \\
(\mathrm{cm})\end{array}$} \\
\hline Notching & Bud location & & \\
\hline \multirow[t]{3}{*}{-} & Top & $5 a$ & $1.0 \mathrm{a}$ \\
\hline & Side & $0 \mathrm{a}$ & $0.3 \mathrm{a}$ \\
\hline & Bottom & $0 \mathrm{a}$ & $0.1 \mathrm{a}$ \\
\hline \multirow[t]{3}{*}{+} & Top & $46 \mathrm{a}$ & $15.1 \mathrm{a}$ \\
\hline & Side & $35 \mathrm{~b}$ & $9.3 \mathrm{~b}$ \\
\hline & Bottom & $15 \mathrm{c}$ & $4.8 \mathrm{~b}$ \\
\hline \multicolumn{4}{|c|}{ Significance } \\
\hline \multicolumn{2}{|c|}{ Notching (N) } & $* * *$ & $* *$ \\
\hline \multicolumn{2}{|c|}{ Bud location (L) } & $* * *$ & $* *$ \\
\hline \multicolumn{2}{|l|}{$\mathrm{N} \times \mathrm{L}$} & $* * *$ & $*$ \\
\hline
\end{tabular}

$\overline{{ }^{2} \text { Mean separation within notching treatment by Duncan's multiple range }}$ test, $P \leq 0.05$.

*,**,*** Significant at $P \leq 0.05,0.01$, or 0.001 , respectively. 


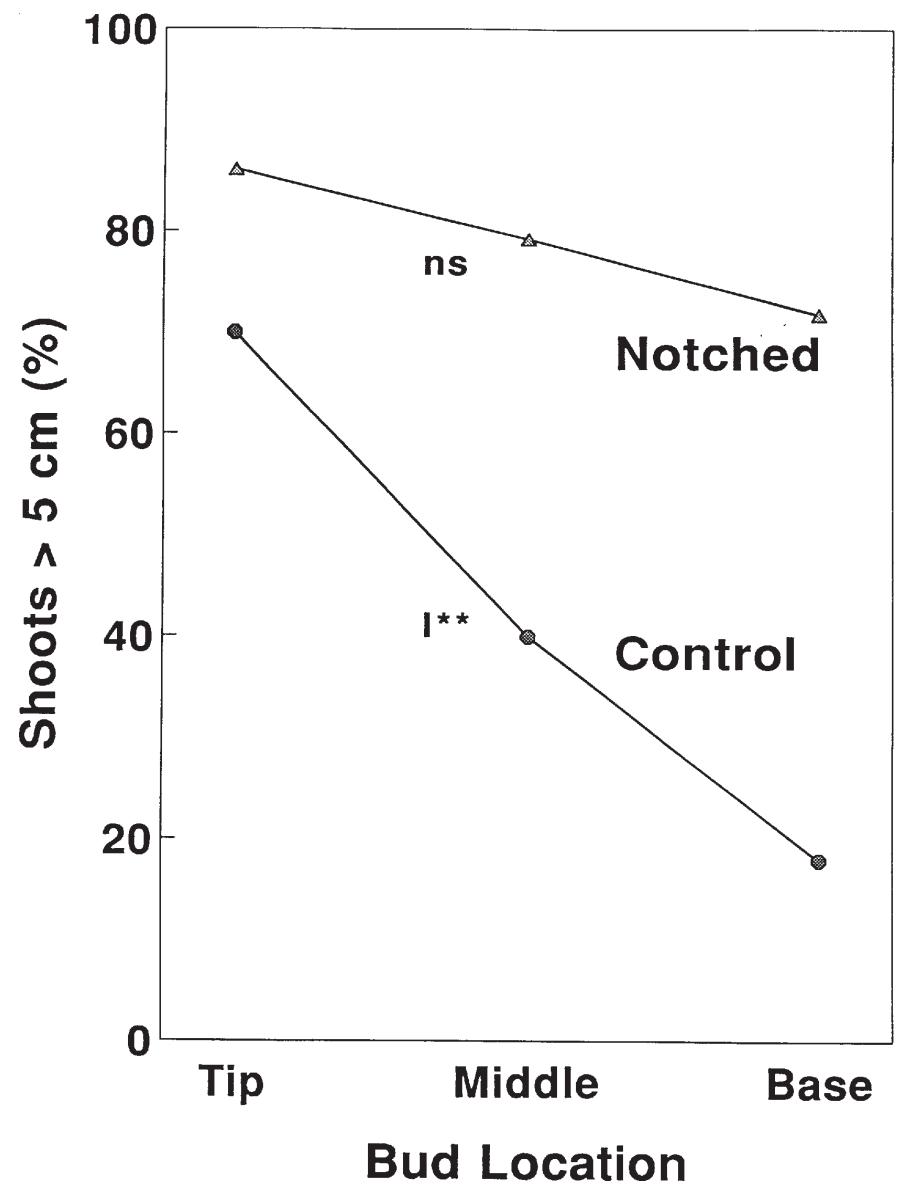

Fig. 2. Effect of notching and bud location on the incidence of shoot production of 'Spurcort Cortland'-M.7. There was no location effect on notched buds, whereas control buds were significantly affected by location $(P \leq 0.01)$.

Table 3. Effect of notching above buds on 1-year-old wood and of Promalin treatment on incidence of shoot production and shoot length of 'Spurcort'-M.7 as influenced by bud location on the shoot and by shoot type (Expt. 3).

\begin{tabular}{|c|c|c|}
\hline Treatment & $\begin{array}{c}\text { Shoots } \\
\geq 5 \mathrm{~cm} \\
(\%)\end{array}$ & $\begin{array}{l}\text { Shoot } \\
\text { length } \\
(\mathrm{cm})\end{array}$ \\
\hline No notching & 43 & 7.8 \\
\hline Notching & 79 & 19.5 \\
\hline No Promalin & 53 & 13.4 \\
\hline Promalin & 69 & 13.0 \\
\hline Central leader & --- & 16.8 \\
\hline Scaffold & --- & 12.6 \\
\hline \multicolumn{3}{|l|}{ Bud location } \\
\hline Shoot tip & 78 & 16.6 \\
\hline Middle of shoot & 60 & 12.4 \\
\hline Shoot base & 45 & 10.5 \\
\hline \multicolumn{3}{|l|}{ Significance } \\
\hline Notching $(\mathrm{N})$ & $* *$ & $* * *$ \\
\hline Promalin $(\mathrm{P})$ & $* * *$ & NS \\
\hline Scaffold vs. Central leader & --- & $* * *$ \\
\hline Bud location (L) & $* * *$ & $*$ \\
\hline $\mathrm{N} \times \mathrm{P}$ & NS & $* * *$ \\
\hline $\mathrm{N} \times \mathrm{S}$ & --- & NS \\
\hline $\mathrm{N} \times \mathrm{L}$ & $* * *$ & $* *$ \\
\hline $\mathrm{N} \times \mathrm{S} \times \mathrm{L}$ & $*$ & NS \\
\hline
\end{tabular}
tively.
Promalin interaction on shoot length (Table 3). Shoots that grew from notched buds were longer than those growing from buds that were not notched. The length of shoots growing from Promalin-treated buds was similar to those growing from untreated buds. There was also a notching $\times$ location interaction on shoot length (Fig. 3). When buds were not notched, shoots growing from buds at the tip of a shoot were longer than those growing from buds in the middle or at the base of a shoot. This relationship was highly significant, negative, and linear. However, if buds were notched, shoot length was similar, regardless of bud location.

Age of wood and bud location (Expt. 4). Notching increased branching similarly at all three locations on the central leader of 'Marshall McIntosh' (Table 4). There were notching $\times$ wood age, notching $\times$ location, and notching $\times$ wood age $\times$ location interactions (Fig. 4) on shoot initiation. All buds notched on 2-year-old wood grew into lateral shoots, whereas slightly $>80 \%$ of the buds on 1-year-old wood produced shoots $>5 \mathrm{~cm}$. More buds that were not notched in the youngest portion of 1- or 2-year-old wood grew into lateral shoots than from buds located in the middle or the older portion. When buds were not notched, considerably more buds in the youngest portion of 1-year-old wood grew into lateral shoots than similar buds located on 2-year-old wood. Shoot growth was substantially longer from notched buds than from buds that were not notched. Shoots that grew from 2-year-old wood were longer than those that grew from 1-year-old wood. There was a notching $x$ wood age interaction on shoot length. When buds were not notched, the average length of shoots developing from these buds was $<10 \mathrm{~cm}$ on 1- and 2-year-old wood. If buds were notched, average shoot growth differed between 1- and 2-year-old wood

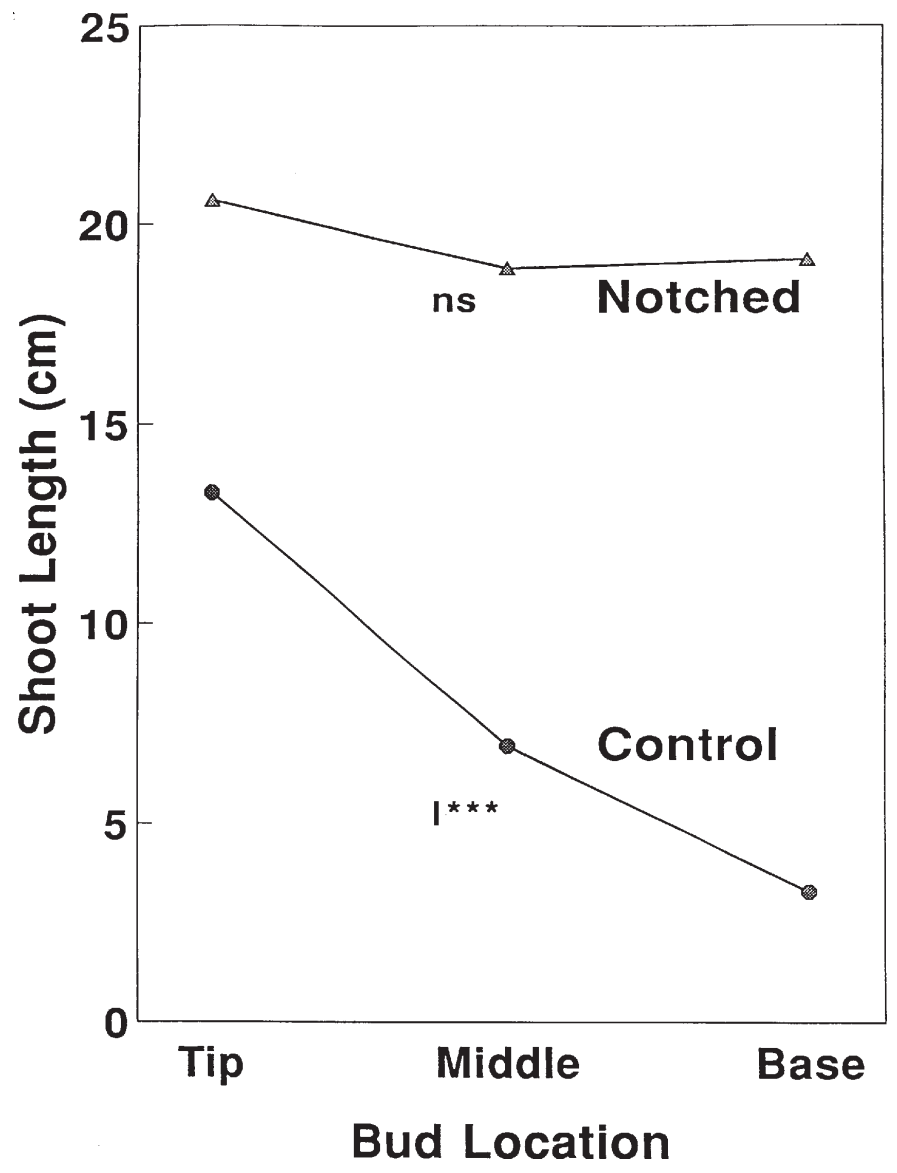

Fig. 3. Effect of notching and bud location on shoot length on 'Spurcort Cortland'M.7. There was no location effect on notched buds, whereas control buds were significantly affected by location $(P \leq 0.001)$. 
Table 4. Effect of wood age and bud location on shoot formation of 3-year-old 'Marshall McIntosh'-Mark in response to notching above buds on the 1- or 2-year-old portion of the central leader (Expt. 4).

\begin{tabular}{lcr}
\hline \hline & $\begin{array}{c}\text { Shoots } \\
\geq 5 \mathrm{~cm}\end{array}$ & $\begin{array}{r}\text { Shoot } \\
\text { length } \\
(\mathrm{cm})\end{array}$ \\
Treatment & $(\%)$ & 7.8 \\
\hline No notching & 20.4 & 52.4 \\
Notching & 92.8 & 22.5 \\
1-Year-old wood & 55.7 & 36.5 \\
2-Year-old wood & 57.5 & \\
Bud location & & 29.7 \\
At tip & 67.4 & 30.7 \\
In middle & 54.4 & 28.9 \\
At base & 48.1 & \\
Significance & & $* * *$ \\
Notch (N) & $* * *$ & NS \\
Wood age (A) & NS & $* * *$ \\
Bud location (L) & $* * *$ & $* *$ \\
$\mathrm{~N} \times \mathrm{A}$ & $* *$ & $\mathrm{NS}$ \\
$\mathrm{N} \times \mathrm{L}$ & $* *$ & $\mathrm{NS}$
\end{tabular}

Ns,*,****** Nonsignificant or significant at $P \leq 0.05,0.01$, or 0.001 , respectively.

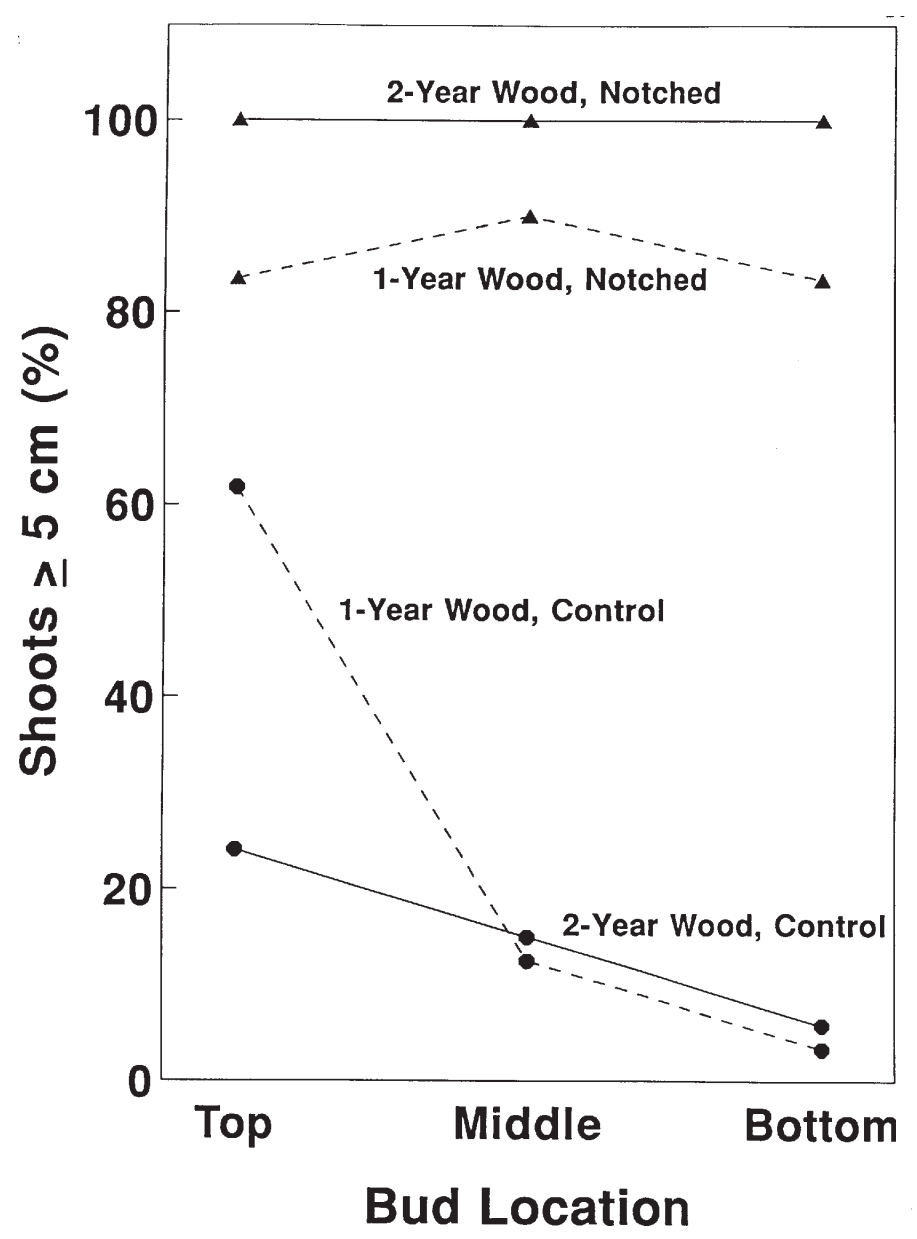

Fig. 4. Effect of notching, wood age, and bud location on incidence of shoot production of 'Marshall McIntosh'-M.26.
(39.5 cm from 1-year-old wood and $65.3 \mathrm{~cm}$ from 2-year-old wood).

Bud size (Expt. 5). Notching stimulated lateral branching and increased the length of lateral shoots (Table 5). As bud diameter increased, there was a highly significant linear increase in the number of buds growing into lateral shoots and the length of these lateral shoots. This relationship occurred on buds that were notched and on those that were not notched. Notching did not influence fruit set (data not shown).

\section{Discussion}

Notching stimulates lateral branching by interrupting the downward movement of auxin from the shoot tip (Tamas, 1987). As long as the phloem remains severed and auxin is prevented from reaching the lateral bud, growth and development of that bud will not be inhibited. Apparently, the critical period to relieve a bud from apical dominance for maximum lateral shoot growth is 2 to 4 weeks before full bloom. We speculate that reduced effectiveness when notching is done early is due to early healing of the notch, a response that allows the apical shoot to reimpose apical dominance.

Shoot growth is characterized by a sigmoid growth curve (Leopold and Kriedemann, 1975). Apple shoots grow most rapidly immediately after bloom. If notching is done just before or during this period of most active shoot growth, the potential for bud growth is proportionately diminished. Therefore, buds notched at full bloom and 2 weeks later grew less than buds notched 2 to 4 weeks earlier.

Bud size is a dependable measure of bud vigor and growth potential. There is a direct positive relationship between apple bud size and the number of leaf primordia, and, after bud break, ultimate leaf count and leaf area produced by the bud (Felber, 1948). If apple buds are small, they may never initiate shoot growth in the spring. We confirmed these observations on buds that were not notched. Further, notching significantly increased the growth of buds in all size categories, but clearly the most vigorous buds were more likely to develop into a lateral shoot than small buds.

Lateral bud break and shoot growth occurs preferentially at the tips of upright and unheaded branches (Oberhofer, 1990), and frequently this location is where large axillary buds on nonspur-type trees are found (Walsh, 1979). This distribution of growth was confirmed on 'Spurcort' and 'Marshall McIntosh', for which there was a significant linear reduction from tip to base in bud break and shoot growth. Notching altered the natural growth response of

Table 5. Effect of notching above buds and of bud diameter on the incidence of shoot production and shoot length of 4-year-old 'Marshall McIntosh'-Mark (Expt. 5).

\begin{tabular}{|c|c|c|c|}
\hline \multicolumn{2}{|c|}{ Treatment } & \multirow{2}{*}{$\begin{array}{l}\text { Shoots } \\
\geq 5 \mathrm{~cm} \\
(\%)\end{array}$} & \multirow{2}{*}{$\begin{array}{l}\text { Shoot } \\
\text { length } \\
(\mathrm{cm})\end{array}$} \\
\hline Notching & $\begin{array}{l}\text { Bud diam } \\
\text { (mm) }\end{array}$ & & \\
\hline- & & 16.8 & $\overline{5.0}$ \\
\hline+ & & 71.8 & 21.9 \\
\hline & 3.7 & 28.9 & 9.2 \\
\hline & 4.7 & 47.2 & 12.9 \\
\hline & 5.7 & 59.1 & 19.5 \\
\hline \multicolumn{4}{|l|}{ Significance } \\
\hline Notching $(\mathrm{N})$ & & $* * *$ & $* * *$ \\
\hline Bud diameter (B) & & $\mathrm{L}^{* * *}$ & $\mathrm{~L}^{* * *}$ \\
\hline $\mathrm{N} \times \mathrm{B}$ & & NS & NS \\
\hline
\end{tabular}

${ }_{\mathrm{Ns},}{ }^{* * * *}$ Nonsignificant or significant at $P \leq 0.001$, respectively; $\mathrm{L}=$ linear. 
upright shoots by increasing bud break and shoot growth similarly, regardless of bud location on the shoot.

The growth of lateral buds is inhibited by apical dominance and geotropism on branches that are positioned at some degree from the vertical (Kaufman and Song, 1987). Buds on the upper portion of such branches break preferentially to those located either on the side or bottom of the branch (Oberhofer, 1990). Notching reinforced the natural tendency of buds on the top of a branch to break, but it was less effective at encouraging other buds to break. Notching was able to overcome bud inhibition imposed by a shoot apex by preventing the movement of auxin to the bud, but it was not able to overcome inhibition due to geotropism.

Notching per se does not seem to be as important as the amount of bark removed above each bud. In this investigation, $\approx 2 \mathrm{~mm}$ of bark was removed with a hacksaw blade. Verner (1955) notched buds using two 2-mm-wide incisions. Cuts or notching procedures that remove $<2 \mathrm{~mm}$ of bark may be less effective because the wound may heal and reimpose apical dominance before the bud has grown sufficiently to become immune to the effects of the shoots growing above.

Shoots that develop from notched buds frequently have a sharper crotch angle than shoots that develop from buds that were not notched (Greene and Miller, 1988; Verner, 1955). Angles of notched buds can be improved by using clothes pins, weights, or BA (Greene and Miller, 1988). However, unless angles are much $<50^{\circ}$ from vertical, this detrimental aspect of notching will be of little practical consequence and will require no remedial action.

Notching was consistently effective. When all data over all experiments and years were pooled, notching increased the chance of a bud growing into a lateral shoot by $\approx 600 \%$. If large buds were selected on vigorous wood and notching was done between green tip and $1.2 \mathrm{~cm}$ green stages of bud development, one could reasonably expect $>80 \%$ of the notched buds to grow into lateral shoots.

We believe, for several reasons, that notching is the most effective technique available to stimulate lateral shoot growth on apple trees. First, it is rapid. A bud can be notched in $<5 \mathrm{sec}$. Second, buds can be stimulated to grow in precisely the place where they are wanted. Third, growth, fruit set, and flower bud formation are not adversely affected. Fourth, shoots that are stimulated to grow with notching are frequently longer and more useful than those induced by other means.

\section{Literature Cited}

Auchter, E.C. and H.B. Knapp. 1929. Orchard and small fruit culture. Wiley, New York.

Chandler, W.H. 1925. Fruit growing. Riverside Press, Cambridge.

Elfving, D.C. 1985. Comparison of cytokinin and apical dominance-inhibiting growth regulators for lateral-branch induction in nursery and orchard apple trees. J. Hort. Sci. 60:447-454.

Elfving, D.C. and C.G. Forshey. 1976. Growth and fruiting responses of vigorous apple branches to pruning and branch orientation treatments. J. Amer. Soc. Hort. Sci. 101:290-293.

Felber, I.M. 1948. Growth potential of vegetative buds on apple trees. J. Agr. Res. 77:239-252.

Ferree, D.C. 1981. Physiological aspects of pruning and training, p. 90104. In: R.B. Tukey and M.W. Williams (eds.). Tree fruit growth regulators and chemical thinning. Washington State Univ. Coop. Ext. Serv., Pullman.

Forshey, C.G. 1982. Branching responses of young apple trees to application of 6-benzylamino purine and gibberellin $\mathrm{A}_{4+7}$. J. Amer. Soc. Hort. Sci. 107:538-541.

Gardner, V.R., F.C. Bradford, and H.D. Hooker, Jr. 1939. The fundamentals of fruit production. McGraw-Hill, New York.

Greene, D.W., W.R. Autio, and P. Miller. 1990. Thinning activity of benzyladenine on several apple cultivars. J. Amer. Soc. Hort. Sci. 115:394-400.

Greene, D.W. and P. Miller. 1988. Effects of growth regulator sprays and notching on growth and branching of 'Starkrimson Delicious' apple trees. J. Amer. Soc. Hort. Sci. 113:18-23.

Kaufman, P.B. and I. Song. 1987. Hormones and the orientation of growth, p. 375-392. In: P.T. Davies (ed.). Plant hormones and their role in plant growth and development. Martinus Nijhoff Publishers, Dordrecht, The Netherlands.

Leopold, A.C. and P.E. Kriedemann. 1975. Plant growth and development,. 2nd ed. McGraw-Hill, New York.

Looney, N.E. 1980. Growth regulator use in commercial apple production, p. 409-418. In: F. Shoog (ed.). Plant growth substances, 1979. Springer-Verlag, Berlin.

Lord, W.J. and R A. Damon. 1983. Growth and fruiting response of 'Redspur Delicious' apple trees to pruning treatments. J. Amer. Soc. Hort. Sci. 108:867-871.

Oberhofer, H. 1990. Pruning the slender spindle (English translation). British Columbia Ministry of Agr. Fisheries Bul.

Popenoe, J. and B.H. Barritt. 1988. Branch induction by growth regulators and leaf removal in 'Delicious' apple nursery stock. HortScience 23:859862.

Quinlan, J.D. and A.P. Preston. 1978. The use of branching agents to replace hand pruning of young trees of Bramley's Seedling apple. J. Hort. Sci. 53:39-43.

Swales, J.E. 1976. Commercial apple growing in British Columbia. Ministry of Agr., Victoria, B.C.

Tamas, I A. 1987. Hormonal regulation of apical dominance, p. 393-410. In: P.T. Davies (ed.). Plant hormones and their role in plant growth and development. Martinus Nijhoff Publishers, Dordrecht, The Netherlands.

Verner, L. 1955. Hormone relations in the growth and training of apple trees. Univ. Idaho Expt. Sta. Res. Bul. 28.

Walsh, C.S. 1979. The effects of node position, shoot vigor, and strain on 'Delicious' apple spur development. J. Amer. Soc. Hort. Sci. 104:825828.

Wertheim, S.J. 1978. Manual and chemical induction of side shoot formation in apple trees in the nursery. Scientia Hort. 9:337-346. 